\title{
$28 \begin{aligned} & \text { Experiences with the } \\ & \text { Metaphysics of Nature }\end{aligned}$
}

\author{
Michael J. Roads
}

\section{CONTENTS}

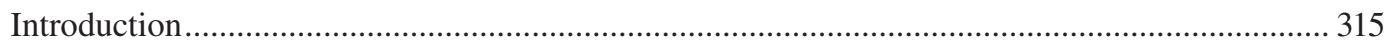

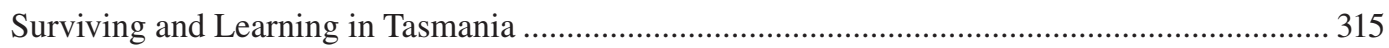

Goodbye Tasmania ... Hello Organic Farming Consultancy.................................................... 320

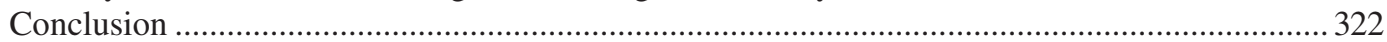

\section{INTRODUCTION}

I grew up in a farming family in East Anglia, UK, working with my father until his untimely death in the early 1960s. With my wife and I in our mid-twenties, and with two young children, we then emigrated to Tasmania, the island state of Australia. It was there that I experienced many of the deeper insights of Nature that I share with you now.

I will begin by explaining about energy. My early years of working with the metaphysics of Nature were by trial and error, interlaced with a fair degree of common sense. What I have learned is that everything is energy. All space and matter is energy and all energy is information. Another name for this energy is consciousness. So, here, we have a vast reservoir of information that is not physically visible or available and is thus ignored, despite being metaphysically obtainable.

Over my many years of experience and study, I have learnt that the metaphysical precedes the physical. That we are unaware of this makes no difference to reality. However, if you accept this higher reality and work with it, life as a farmer becomes very different, very interesting. You accept what you can physically see, but you acknowledge that if you learn to work with the unseen, then the results will be far greater than before. It follows that, just as Nature is far more than we can see, so also are you. I have written several books on this topic of the metaphysical world of Nature and have lectured internationally on this subject. My books, Talking with Nature (1985) and Journey into Nature (1990), both best-sellers, are still in publication under a single cover. In addition, Conscious Gardening (2008) has been well received, and I have also explored the astral worlds of Nature in my book, Stepping between Realities, published in 2014. My latest book is Entering the Secret World of Nature.

\section{SURVIVING AND LEARNING IN TASMANIA}

When I emigrated at aged 26 with my late wife and 2 young children, I went from an arable farm in Cambridgeshire, England, to a beef farm in Tasmania, the island state of Australia. This was in November 1963. There is of course a huge difference between these two types of farming, in two very different countries with very different climates, but we were young and full of confidence, and the scale of this challenge was easy to dismiss at the start. This was our choice. What I did not choose was a plague of armyworm caterpillars that, like a swarm of locusts, crawled across my 354 acres on the foothills of Mt Arthur and devastated my pasture. My cows drank from waterholes that were so full of dead caterpillars that the living ones could crawl over the surface. Within 
2 weeks, I was walking around my farm shooting my very sick, poisoned and starving herd of beef cattle. Quite a shocking and very sobering introduction to farming in Tasmania!

For economic survival, I became a reluctant dairy farmer. I will skip the many trials and tribulations I endured during the worst decade of farming of the twentieth century in Tasmania. But it was under this constant pressure that my new relationship with Nature and agriculture was born ... and grew.

What gradually hit me so powerfully was how poorly equipped and uneducated I was to change both my country and my farming practice in one move. And yet, it was this sheer lack of knowledge that pushed me in a very different direction. Realising how much I did not know, I turned towards my hitherto unexplored intuition. Intuition said that if I wanted to learn about pastures and cows, then I should ask them. Initially, I had trouble with this ... but I did it. I walked out into the middle of a 30-acre paddock and, sitting down, I did my best to attune with the land. I had little idea of what I was doing, so I focused on my farm, my cows and myself. In those distant days, I had no idea of a simple universal principle: Where you focus energy flows, and connects, and creates.

It took me a while to find a measure of inner quiet, but over a period of maybe a couple of hours or so, I suddenly became aware of having answers to my varied questions. This shook me. They seemed to come from nowhere, but the answers carried a fair degree of certainty. How was this possible? However, in good faith, I applied all that I had apparently learned to the problems I had ... and it all worked. All the deep insights proved to be valid and invaluable. And so a whole new education began.

My cows became my main teachers, beginning with one particular young cow. One of my dairy heifers had become paralysed as the result of birthing her first, rather overlarge calf. In the early 1970s, generally, if a cow was 'down' for more than 2 or 3 days, she would die. However, I noticed that no crows hung around her. My observations indicated that if the local crows attended a cow, she would almost always die, no matter how you treated her. So morning and night, every day for 10 days, I fed and hand-milked her, rolling her from one side to the other. On the tenth day, she struggled to get to her feet and, with my help, she managed. During this struggle for her life, we bonded, and she became my 'cow teacher'.

'Awkward' - as I named her because she now had an awkward walking gait - and I spent many odd hours as companions while she grazed. We would walk together, and when she lay down, I would sit leaning against her side. It was she who taught me most about the varying energies of the land. There were areas in a 50-acre paddock where my 100 milking cows would never lie down. Never. Based on no reasons that were visible, there were other areas they would congregate in. When I lay down where cows would not, I sensed a feeling of discord, out of harmony with the land. Not good or bad, or right or wrong, just a strange unsettling feeling of disquiet. When I lay carefully - where the cows congregated, I felt fully at ease, in harmony with the land. Conclusion: never build a house where the cows will not lie down!

I was not able to talk with my farming friends about learning the varying energies of the land from a cow. I was already 'the Mad Englishman on the hill!' Nevertheless, when I sat with Awkward while she chewed her cud, I would go into a dreamy, half-meditative state of deeper consciousness and emerge into a very different world of energy. In this world, I was told that the paralysis of Awkward was not an accident. It was a test to see how I would respond to her situation.

I confess, many times during the 10 days of attending her I wondered why I was doing this. Every farmer knew that 2 or 3 days was the limit. Despite this, I persisted and I was rather proud of getting the cow back onto her feet. Now, I was learning that farming was all about the qualities I expressed as a farmer and the patience and compassion I had towards both the land and my livestock.

Under the tuition of this metaphysical aspect of Awkward, I learned more about cows than any book ever written could teach me. Certainly, books could and did teach me about the physical anatomy of a cow, but just as humans are not mortal body/personalities, they are immortal souls, so also a cow is far more than the physical anatomy. I learned to interpret the body language of all my cows from an intuitive perspective. I learned to know what it is to be a cow. I learned how the 
herd is a group soul, with each individual cow an aspect of that. I learned that each soul as a part also held the blueprint of the whole ... and that separation is an illusion created by our intellectual beliefs. We do not think holistically.

Awkward showed me the energies of the land. To most farmers, soil is just soil, land is just land, good, bad, or indifferent. This is not so. Just as with all life, soil is living. By this, I do not mean only the micro- and macro-life teeming within the soil, I also include the mineral aspects of the soil as particulates. Everything is energy. If I viewed the soil as dead or half-dead, as a substrate that I had to somehow grow living pasture upon, then I would create my own opposition to this growth. Not only this, but I would unwittingly create the conditions that would support my belief that the soil is dead rather than living. Conditions such as drought, or excessive rain, or subsoil hardpans may all be collectively created by unwitting farmers. As I said earlier, it is all about energy.

Farming is more about the wielding of consciousness than almost anything else. We have not even begun to farm the land, we only think we do. Most farmers are like people attempting to follow a path with their eyes closed. This does not make them bad or wrong, but we do need to awaken to a new and vital era of more enlightened agriculture. I concede, however, that it is a huge leap forward. Bio- or organic farming was and is a wonderful first step, but this next quantum step is long overdue.

As a dairy farmer, I had a serious problem. I feel a touch of embarrassment to admit that even though I truly liked my cows ... I hated milking. It took me only 8 weeks to learn how much I detested the regular, monotonous work of milking twice a day, every day. Fortunately, I had no idea that I would spend the next 8 years milking them, but in hindsight, I realise that this was the perfect way to teach a person completely lacking in self-discipline, and this was something that I greatly needed in my life. My hate of milking meant that I was mostly bad-tempered in the milking shed. The cows picked up on my energy and liberally doused the whole milking shed in hot, green, liquid poo! They kicked and were continually agitated, making the process of milking far more laborious than it needed to be. As far as I was concerned, however, it was all their fault, not mine!

Only a few weeks after my association with Awkward started to deepen and develop, an incident happened in the milking shed that began a major change my life.

I brought the cows in as usual with my trained cattle dogs, and in a particularly bad mood, I commenced milking. One of my skittish, long-legged Friesians came towards the milking stall, and just as she entered, she kicked out at me. She caught me a heavy whack on the quad muscle of my thigh, the leg going instantly numb. As I struggled not to fall over, my rage boiled and I did something I had never done before. Picking up the leg-chain, I swung it in an arc around my head, before bringing it down towards her ribs as hard as I could.

It all went horribly wrong ... or perhaps I should say, it all went perfectly right!

As the leg-chain approached her ribs, she danced out the way and again kicked out. The leg-chain caught on her ankle, and she kicked again. Now, in a blur of speed, the leg-chain did a double arc and was hurtling towards my head. I automatically put up my arm to stop it. The next thing I knew was a terrible, agonising pain as the leg-chain wrapped around my arm. The pain was so bad I did not know whether to vomit or faint, but I managed to do neither. However, in that moment of intense pain, powerful words were forcibly and indelibly imprinted into my consciousness: 'I did this to myself'.

In that moment of agony, I knew that I was the cause of all the chaos and turmoil in the dairy. I knew that I was the author of my pain ... and in that moment, my consciousness changed. In what way exactly, I had no idea, but I knew I was changed. It was 4 days before I could milk again. My arm was black-blue and purple. It was 4 months before the bruise finally left the bone in my forearm and I was without pain. But the results were remarkable. I had changed.

Within myself, I knew I had changed. When I was able to recommence milking, every cow was quiet, no agitation, no chaos, no hot green poo all over the place. My frustration at milking, my anger, had vanished. It gradually dawned on me that every one of my hundred milking cows knew that I had changed. From then onwards, the mayhem of the previous 2 years in the milking shed ended because my anger had disappeared. The cows were aware of my changed state of 
consciousness. Our shared consciousnesses, although very different as man and cows, were as One. It took me a while to embrace this.

However, among all my friends and even my family, only my wife knew that I had changed - not a single other person I knew. I mentioned the change to a couple of very close friends, and they even laughed at me. It was very sobering to know that humans with whom I shared consciousness were, in fact, far less conscious of this change than my cows. Eventually, I was to learn that humanity lives largely subconsciously, while all animals live fully in a conscious state. This is a huge subject that I will not pursue in these pages.

I later asked the metaphysical aspect of Awkward if she had anything to do with what had happened. What she told me was a shock. 'It is all about timing. Eggs hatch at the perfect time, and so do buds unfold. The bud of your potential needed a great shock to bring you to a higher level of consciousness'. I asked why. 'Because like so many humans you are into trauma and drama as a stimulant for inner growth. Pain is the usual supplier for this'. (I should add that I no longer use such techniques for inner growth!)

Most people are unaware of the energies of life. As I developed my ability to go ever deeper into the metaphysical world, so I learned that Chaos - the engine that drives, Order - the stability of structure, and Balance - the place of highest potential, are the energies that govern all life. For me, Chaos is a range of about a thousand shades of red. Each shade has a different energetic expression, ranging from a red of extraordinary grace to a red of extreme rage and on to pure wordlessness. I struggle to explain this as it is purely metaphysical, and for this, we have no language. Order, for me, is in the range of the colour black and also has a vast diversity of meanings. Balance is a flickering pure white, which has the greatest energy of all. I have named these energies Chaos, Order and Balance with capitals simply because these words are the best fit. I need to say that I experience these all on an emotional, not intellectual, level. They suggest to me that we are on the cusp of developing an emotional language that far exceeds our mental one, but this is all tied to our state of consciousness. Imagine you have a thick rope. You are twisting it to the right, Chaos, and your friend is twisting it to the left, Order. This twisting in opposite directions creates torsion in the rope. Too much either way and the torsion is out of balance. However, if the twisting is equalised, the torsion moves into Balance. In a way, Chaos and Order are in direct opposition with each other, yet from this comes Balance. As an example, a wildfire is pure Chaos with no Order, while a rock is pure Order with no Chaos. In a sick person, either Chaos or Order is dominant, depending on their condition. In a vital, healthy person, they are in Balance.

As you follow this, you may realise that this principle applies to every living organism, from the tiniest micro to the largest macro forms of life. As an ex-dairy farmer, let me give an example. A human crowd is utter Chaos. Not so in animal herds. Every cow in the herd has the Chaos/ Order dynamic within her. Generally, the more Chaos, the more dominant the cow. This creates the 'pecking' order. The cows are quietly grazing in the paddock. Each cow is always standing in perfect proximity to every other cow in the herd. My cattle dogs move in and hurry all the cows towards the milking shed. The dogs are enthusiastic and the cows are being rushed. All is now Chaos in the herd. They reach the holding yard with the swinging gate, and every cow is in the wrong position with regard to the others. To the degree that they can, they head-knock each other into the right pecking order, but this is hampered by the gate and the cows being steadily taken into the milking stalls.

With the milking finished, the cows congregate either outside the milking shed, or wherever the farmer takes them. They lay down long enough to find their own Chaos/Order/Balance equilibrium before eventually moving away to graze once more in the proper order of dominance. A wise farmer allows time for the cows to rebalance their energy. It is essential for the well-being of the herd.

After completing my 8-year apprenticeship with the cows in the dairy, I reached a turning point. All my milk had until then been separated and some sold as cream. Then, the butter factory said it would only take whole milk to process themselves. So it was either 'get in deeper, or get out'. An easy choice for me! I had been breeding my own beef herd with Hereford bulls over my Frisian 
cows. My bucket-reared heifers were put to the bull in their second year, not the first, so they were beautiful large animals ... and I really loved them. This was also a turning point in my whole relationship with the land and cattle, it was when I truly realised that ... I loved them. It was a time when my connection with the cattle moved to a new level.

I will share an incident involving my developing beef herd. All my ex-dairy cows now ran with my beef cows in one large herd of about 140 cows. I would walk among them almost every day, talking to them, stroking their backs and consciously connecting with them. And I use the words consciously with deliberation. I was not thinking of other things, my whole focus and attention was on the cow herd, and on each cow as I touched her. As I did this, I noticed that one of my large tame heifers was not energetically right. She looked perfect, but her Chaos/Order energy was out of Balance. As I focused on her, my intuition told me that her calf was dead inside her and that she had peritonitis.

Talking to her all the time, I walked her out of the herd and down the steep roadway to the creek. The idea was to cross the creek bridge and up the roadway on the other side to the farm buildings, where I would keep her and phone for the vet. Unfortunately, this did not happen. When we reached the creek, she turned off the roadway and followed the creek. Despite my efforts, I could not stop her. When she reached a narrowing of the creek, she deliberately laid down, effectively damming the flow of the water so that it flowed around and over her. For half an hour, I tried everything to get her out of the freezing cold creek, but she would not budge. Finally, I put a halter on her, and with my Landrover, I dragged her onto the bank. Then leaving her haltered to the vehicle, I walked to my house to phone the vet.

Returning to her immediately, I found she had broken the rope and was back in exactly the same position. I sat down in tears. Cows have their eyes in the sides of their head, so are unable to fully see you. Yet she fully looked at me, an invitation in her eyes. She then swung her head along her back and immersed her head under the deeper water caused by her body. As I watched this through eyes blurred with my tears, I knew, I even felt the pain she was in. Her calf was dead and rotting, and she was suiciding. Every book I have ever read about such topics says that only humans suicide, never animals. I knew and felt that the icy water was numbing her pain and that she was inviting me to metaphysically join with her in this conscious and deliberate process. Sadly, all I could do was cry as I helplessly watch a heifer I loved drown herself.

Metaphysically, all linear time occupies the same moment. Years later when I had grown in consciousness, I visited that moment again, and this time, I accompanied her as she transitioned from a herd-soul on a physical plane to a far greater and more wondrous herd-soul on a higher plane of consciousness. That was when I learned how our conscious human love can raise the consciousness of all animals. Even the farmer using animals for milk or meat can, by conscious love for his or her livestock, raise their consciousness. I will go as far to say that this is what it is to be a true custodian of livestock or of the land. By our good use or misuse, we raise or lower their or its consciousness.

My own personal evolution of consciousness took me away from farming in a way that I did not expect. My relationship with my cattle had been a very close one. One wild and wet night, I had been walking the herd because I knew that this was the weather they preferred for calving, and the old deep instinct of rain washing away the birthing smells from predators was still with them. Every cow so far had calved with no problems, but I knew there was one more to check on. When I found her around $5 \mathrm{am}$, there was enough light for me to see she had licked away and eaten all the afterbirth except for one thick piece on the face of the calf, covering its mouth and nostrils. I cleaned it away, but he was dead. Because he was still warm, I positioned him so that I could push onto his lungs while giving him mouth-to-mouth resuscitation. Just as I was about to give up, he took a deep shuddering breath and was alive! In that moment, I felt an incredible elation, joy, victory, a soaring of my spirit ... which came crashing down as I realised that in 10 months I would be sending him to the slaughterhouse.

That moment finished my beef career. I knew that I could not do this to animal Beings that I loved. If this sounds stupid or emotional, so be it. For me to continue growing in consciousness required that I follow a different path in my physical life. 


\section{GOODBYE TASMANIA ... HELLO ORGANIC FARMING CONSULTANCY}

We sold the farm, and for a year, we travelled with our four children in a caravan on a glorious adventure. Settling temporarily in the Bellingen Valley in NSW, I spent the next several years as an organic farming consultant. I named my business Soil Sense Associates. My practical approach was to have the farmer-clients' soil tested in a laboratory, and the results I would then reconfigure away from the chemical recommendations into organic fertiliser terms. To fertilise means 'to enrich', not to chemically stimulate; a true fertiliser fills the soil pantry, rather than emptying it.

My all-important metaphysical focus was to be conscious of the Spirit of the Land and to communicate with it. In this way, I had a double-barrelled approach, with one foot in the physical and the other in the metaphysical, which proved to be very effective. It all really took off when, in the early 1980s, I gave a public talk in the Darling Downs grain growing area of Queensland. Billed in the local newspaper as the 'Prophet of Natural Farming', the local farmers were shocked to find their meeting hall full with 90 or so people, instead of the regular10-15 farmers. I was no longer a joke.

It so happened that the Darling Downs was an area of very complex soils. Magnesium levels in the soil were higher than the calcium, which caused conditions of concrete-hard soil as it dried out, and clinging mud when wet. Local farming techniques were compounding the problem, which worsened each year. In the talk, I expanded on their problem using terminology that they understood, and even managed to get across some of the metaphysics of the situation.

I won a small number of clients from my talk. A few days later, I was with one of these clients, walking across a fallow field. He was a good farmer, progressive and open to change. He was also very talkative. I had tested his soil, but now I wanted to communicate with the Spirit of the Land. For that, I needed silence and preferably to be alone. Just as I was wondering how I could achieve this, his wife appeared in the distance ahead of us and waved. 'I'm wanted on the phone. I'll be back in about an hour', he said as he walked off. No cell phones in those days!

I smiled, I could now make the connection while he chatted and sipped his coffee.

As I continued across the loose fallow soil, it very strongly came to me that the $\mathrm{pH}$ was changing almost with each of my footsteps. I stopped, puzzled, but all I got was a stronger affirmation of this. I had with me a very sophisticated $\mathrm{pH}$ meter, worth about $\$ 400$, not your local store $\$ 10$ type. I knew it was very reliable. My footsteps were very obvious in the loose dry soil, so I retraced my path taking samples from the soil in my footprints. Sceptical and rather disbelieving, I also took samples 5 metres away from my footprints, and at $10 \mathrm{~m}$ away.

The results gave me a considerable shock. The overall soil in this field was $\mathrm{pH} 9.5$, very alkaline. In my footsteps, it dropped to $\mathrm{pH} 8.3$, an absolutely huge and almost impossible drop. At $5 \mathrm{~m}$ out, it was $\mathrm{pH} 8.9$ and at $10 \mathrm{~m} \mathrm{pH} \mathrm{9.4.} \mathrm{I} \mathrm{rechecked} \mathrm{this} \mathrm{twice,} \mathrm{it} \mathrm{seemed} \mathrm{unreal,} \mathrm{but} \mathrm{the} \mathrm{results} \mathrm{remained.}$

From this, I learned much. Today, I know that the farmer is the very matrix of the farm. What affects the farmer, male or female, affects all the land. There is no exception to this. You may not see, or realise this, but it will be there. The farmers' mood, their anger or inner peace, their depression or happiness, their thinking, their positive or negative energy, their stress, their greed or generosity and their love of farming affected the whole farm. The farmer who truly loves their land and their farming, whether it be horticulture, arable or livestock, is the farmer who is leading the way in consciousness. To these people come the insights and intuitive leaps that most of them have the courage to follow. If you are in the most menial of work, and love what you are doing, love who you are with, and love where you are in life ... then you are a giant in consciousness among humanity.

If you love your farm and the act of farming, you affect the whole because you are the whole. This includes the billions of micro and macro soil life, the livestock, the pastures, the crops, all of it. Just as you are the One, so you are the All. Love reveals this.

I can assure you that no matter how this may not fit in with the rather restrictive beliefs of our current agricultural science ... it remains true. It is also true for a real gardener. By 'real', I mean this does not necessarily apply to the landowner who lets or leases his or her house and garden, or farm and farmland; it applies to the gardener or farmer who is intimately involved with the land itself. 
During my few years as an organic farming consultant, I became aware that if the farmer, or whole family, were constantly sick, the land and livestock struggled to be healthy. Always, the farmer and his or her family were the hinge-pin of the conditions of the soil and the livestock. I also noted that so many farmers battled with Nature on a daily basis. For many, farming was about battling the weeds, the insects and the weather, along with the various political issues over which they held great anger, but could do nothing to control, other than verbally vent their wrath. With this negative energy, their troubles grew and multiplied.

My decade on the foothills of Mt Arthur had taught me that the farm was my meeting place with Nature. I took this very seriously. I considered myself as the student, with the Spirit of the Land as my teacher. This served me very well. I agree that knowledge from other sources has a strong place in agriculture, but I strongly contend that it should not be considered infallible.

When we regard the farm as a complex of energies, with the most complex - the farmer - as the matrix of the energies, we would be wise to understand and integrate these many energies into a compatible amalgam. Agriculture is always going to be a matter of forcing growth if we are unable to comprehend that the $99 \%$ of life that we cannot see is very deeply involved within our methods of farming.

I will share one last aspect of the metaphysics of Nature. I had given a talk in a country town in Victoria, Australia, when I was approached by a farmer. He told me that he had 1,000 sheep and 5 sheepdogs. His problem was the dogs. If let loose, they wandered off the property, and/or would work the sheep, so they were fastened on running chains next to their kennels where they would bark incessantly, driving him and his family crazy. What would I suggest?

I made the usual suggestions, and he had tried them all to no avail. Then, I asked him if his dogs were educated. He replied that yes, they were trained sheepdogs. I asked again if they were educated. This time he asked me what I meant. I asked him if he had ever actually told the dogs what he wanted of them, what they could, and should not, do? He had never even thought of such things. 'They're just dogs', he said.

Because he was obviously full of anxiety and turbulent thoughts, I told him first of all to wait until he was quiet and calm in his head. When he was internally quiet, he should let the dogs off the chains and allow them to first run off their energy. Then, calling them to him, he should walk slowly around the boundary of his farm. All the time he should be focused, consciously telling his dogs that this is their boundary and they do 'not' cross without his permission. Next, he should tell the dogs that he does 'not' want them to work the sheep without his permission. As he walks the boundary with no stray thoughts at all, he should tell them that in return for obeying these requirements, they would no longer be kept on chains. They would be free, so long as they followed his rules. This, I told him, is yours and their education.

I told him that he was the creator on his farm, and it was his choice to make. He huffed a bit and puffed a bit, but we parted on friendly terms. About 8 weeks later, I received a letter from him. No email in those days! He explained that he had thought I was crazy, but he had nothing to lose by giving it a try. To be fair to him, he said it took 4 weeks to quieten his mind, but he managed it. He did as I had told him with the dogs, and with great trepidation did not chain them during the day. Only at night. He was stunned that during those 4 weeks, the dogs had not once strayed or worked the sheep ... and they had stopped the endless barking. Needless to say, he was very grateful.

Under my prompting, he changed his relationship with the dogs to a greater and more accepting one. By doing this, he changed the behaviour of the dogs to a partnership with him, rather than in opposition to him. In other words, he moved their energy from Chaos to a Balance with both him and the farm.

\section{CONCLUSION}

Every farmer has choices. It is far too easy to follow the crowd. Nature speaks to us, we are one energy, one consciousness, something which is outside of conventional thinking. Humanity has 
forgotten how to listen to the world of energy. If agriculture is to have a viable future where farmers return to being custodians of the land, then abusive modern conventional farming has to end. The chemical approach is similar to beating a tired horse with a stick. It may well get a result, but it will only be a short-term one, and that term is now ending: our agribusiness land is in the final stages of erosion and death!

Agribusiness has no heart, no soul, no future. This world is right now going through major shifts, and the metaphysics of farming is in harmony with this change. It is timely now for a more enlightened approach to farming our precious land.

If you, as the reader/farmer, can embrace the reality that you are the very matrix of the land that you farm, you have a future. If you realise that your every thought and emotion stirs the holistic energy of the farm, affecting everything from the micro-organic life in the soil, every plant that grows, all the livestock, the whole caboodle, then you may one day be teaching other people how to manage the land. It is all about conscious connection. You need to know that farmers have the greatest responsibility of anyone; they are the caretakers of the land, of the living soil.

We are moving into new times. All that I have learned in my lifelong connection with Nature indicates that we have to lift our game. Or, it will be game over! Our perception of Nature is a stunted mockery compared with those living in Palaeolithic times. We have become lost in our clever, but stupid, intellects. It is time to return to the wisdom of conscious intelligence. To be innovators: to trust our intuition: to connect with Nature and to once again experience the Oneness of all life.

I am delighted that in our rapidly changing world of today, there are farmers who do see this new way ahead. It is ironic that the new way is a revival of the old way, yet it is a revival with new knowledge and a far deeper insight into the real quantum world of agriculture, offering all the many possibilities of this new perspective. In this quantum world, we should always be aware that the frequency of physical life is low and slow. Your thoughts and emotions are fast, on a far higher frequency, and despite a linear time lag, they will inevitably impact your land and all that lives on it. With this in mind, know that there is no higher energy or greater transformative influence than your ability to use the Power of Love. 